GOSPODARKA SUROWCAMI MINERALNYMI - MINERAL RESOURCES MANAGEMENT

\title{
Financial aspects of changes in the level of finished goods inventory in a mining enterprise
}

\section{Introduction}

Inventory management in any enterprise is an important and current issue within the contemporary economy where most industries and enterprises are functioning under the conditions of a recipients' market and the environment is changing fast, becoming less predictable. Much consideration and research is devoted to this problem, primarily in the logistics branch of management sciences. In this article, the issue of inventory management in an enterprise is presented with regard to financial aspects.

It is worth emphasising that inventory constitutes a highly differentiated group of current assets, including the elements of all manufacturing stages starting from raw materials, merchandise, and advance payments for deliveries, through works in progress and semi-finished products, and ending with finished goods. Taking into account the differentiation of the aforementioned groups, they should be treated in an individual manner, both in a formal way involving such issues as pricing or book-keeping evidence, as well as in a substantial depiction related to the managerial instruments of the particular groups of inventory.

This article's considerations and research are limited to finished goods, with the focus of the research placed within the context of Polish hard coal mining. The research problem is formulated as follows: which factors influence the changes in the inventory levels in Polish

* Ph.D., Silesian University of Technology, Faculty of Organization and Management, Zabrze, Poland; e-mail: izabela.jonek-kowalska@polsl.p 
mining enterprises, and what are the financial consequences of such changes? The main objective is to identify changes in the level of finished goods inventory in a mining enterprise and search for the determinants of the changes.

The theoretical part of the article examines existing literature on finished goods inventory management in a general and branch depiction. The empirical section of the article then presents a case study of the largest Polish mining enterprise in the years of 2003-2012. The final section draws conclusions concerning actions aimed at reducing the negative effects of changes in the level of finished goods inventory within the examined enterprise and Polish hard coal mining.

\title{
1. Inventory management-existing documentation
}

\author{
1.1. Accounting aspects of inventory management \\ in light of the International Accounting Standards (IAS) \\ and Accounting Act
}

From an accounting perspective, inventory is an element of the current assets of an enterprise, meaning that such assets are used within the enterprise's operating activities, and the period of their use does not exceed 12 months. However, the category of inventory is internally differentiated and includes raw materials, merchandise, finished goods, semi-finished products, works-in-progress, and advance payments for deliveries (Walińska, ed. 2010). Such a depiction of inventory corresponds to the hierarchy of their use or creation within the manufacturing process. Raw materials include the ingredients that constitute a manufacturing input; works-in-progress are not yet completed goods; semi-finished products are not fully processed elements but they may be sold if needed; finished goods are fully processed. Merchandise is categorized separately as it is a component bought from other enterprises with the intention of future sales, or constitutes ownership of finished goods sold in the manufacturer's commercial chain (Bakk, ed. 2003; Kiedrowska, ed. 2004).

For each of the aforementioned groups of inventory, there are individualised accounting valuation rules adopted which are defined within the accounting policy of the enterprise. Thus, for raw materials and merchandise, the enterprise may use the purchase or acquisition price for finished goods and for works-in-progress; the cost of manufacturing is a basis for valuation (Dadacz 2012). The manufacturing costs of products include the costs that are directly related to a particular product, while part of the costs are indirectly connected with the manufacturing of the product. The direct costs consist of the value of use of direct materials, the costs of obtaining and processing the materials directly connected with the manufacturing process, and other costs borne in bringing the product to the form and place that it takes on the valuation day. The justified part of indirect costs, which is adequate to the period of product manufacturing, includes the indirect variable costs of manufacturing as 
well as the part of indirect fixed costs of manufacturing that correspond to the level of such costs during a regular use of production capacities. ${ }^{1}$

Considering a reduction of the topic of the article to finished goods, it is worth extending the aspect of valuation of this component and emphasising that the cost of manufacturing does not contain the following costs:

1) the cost being a consequence of unused production capacity and production losses,

2) overhead costs that are not connected with bringing the product to the form and place in which it is set on the valuation day,

3) finished goods and semi-finished product storage, unless bearing these costs is necessary within the manufacturing process,

4) costs of product sales (Turyna 2008).

The costs above are recorded in the financial results of the reporting period in which they occurred.

Moreover, in cases justified by a necessary, long-term product preparation for sale or a long-term period of product manufacturing, the cost of manufacturing may be increased by the costs of liability servicing incurred in order to finance the produced inventory during the period of its preparation for sale or manufacturing, and also accompanying exchange rate differences, decreased by revenues on the differences.

Based on the above, in order to make a proper valuation of finished goods it is necessary to identify the direct and indirect fixed and variable costs correctly. This is a task conducted in branches of management accounting using properly selected cost accounting (Grądzka 2009; Sobańska, ed. 2009; Nowak 2010). However, if the enterprise uses only financial accounting (Czerny 2009), then determination of the cost of manufacturing may be made in a simplified manner. The operating costs could be directly transferred to the financial result or net sales. Nevertheless, such conduct does not result in reliable information about the real level of the cost of manufacturing, which is required for making managerial decisions.

When presenting the problem of balance sheet inventory valuation, it is worth considering the subject of its revaluation. This may occur when inventory has lost economic usability or its balance sheet value is higher than the market value that can be obtained after being evaluated in a reliable way.

The issue of inventory in financial accounting also appears in the context of profits and losses (Samelak 2005). In the Polish system of financial reporting, this account may be conducted according to two variants-by type or by function.

In the first of the aforementioned accounts, the costs are evidenced in a generic cost account-that is, cost accounting by type of expenditure-and in the second one in a functional cost account-that is, by place of occurrence. In the variant by function, the cost of sales is determined in a direct way using cost accounting in the accounts distinguished in this variant.

\footnotetext{
1 A regular usage level of production capacity according to the International Accounting Standard No. 2 is thought to be production on an average level, which is expected to be achieved during a few periods or seasons under typical circumstances with the inclusion of production capacity loss due to a planned overhaul.
} 
In the version by type, the costs and revenues need to be adjusted by a so-called change in the balance of inventory in order to provide a reliable time comparison.

\subsection{Financial aspects of inventory management-existing documentation}

The financial aspects of inventory management may also be related to their role in the production process. Different methods are used for raw materials and merchandise, works-in-progress and semi-finished products, and finished goods. A key objective of inventory management still remains to optimise (Xu et al. 2012; Agrawal and Smith 2013) levels which provide a minimisation of direct and indirect costs of inventory maintenance-inventoriable costs-and at the same time, provide for a continuation of supplies and sales (Guan and Zhao 2011).

Direct inventoriable costs include the costs of storage, insurance, and transport, as well as the wear and ageing of inventory. In turn, indirect inventoriable costs are connected with freezing financial capital in inventory and the loss of alternative possibilities of using these resources. In practice, this indicates a necessity for financing inventory from debt capital or equity and covering the costs of obtaining such capital (Sierpińska and Jachna 2007).

Management of finished goods itself is a topic from the border of logistics and marketing. On the one hand, it concerns the issue of distribution chain organisation for finished goods (Relvas et al. 2013; Andersson et al. 2010). On the other hand, it is linked to using the tools to support the sales processes that are implemented according to the promotion strategy (Wanke 2008).

These days, research on inventory management is primarily concentrated on using statistical, econometric, and computer calculation techniques in the process of particular areas of supplies optimisation (Schwartz et al. 2006; Hamisu et al. 2013; Yüzgec et al. 2010). In this area, both issues are localised concerning the cyclic and repeatable processes of supply and sales, as well as disturbances difficult to predict that accompany those processes (Ozguven and Ozbay 2013; Mason et al. 2012; Magda et al. 2009).

In finished goods inventory management, the problem of finished goods sales is one of the key issues. It may lead to an occurrence of excessive stock from a short-term perspective, and from a long-term perspective it may contribute to the enterprise's fall. As a result of finished goods accumulation, the direct and indirect inventoriable costs rise, the inventory turnover period is prolonged, and cash flow for the operating activities of the enterprise is decreased.

The reasons for problems with finished goods sales may be varied. Goods may not find recipients due to a high price and/or cost of manufacturing, bad quality, the wrong type of technology used, and also due to the occurrence of substitute goods or price decreases of the existing substitutes. The determinants of finished goods sales also include the prices of complementary goods, consumer income and preferences, as well as demographical, geographical, and political factors of a domestic and international character. 


\section{Research methodology and results}

\subsection{Methodology of research conducted}

This section presents a case study on the subject of finished goods inventory of the largest mining enterprise in Poland. The enterprise conducts its activities in the form of a joint-stock company, being the property of the State Treasury since 2003. Currently, there are 15 collieries functioning within its structure (Turek and Jonek-Kowalska 2010).

The research period includes the period of 2003-2012 and consists of the following research stages:

1) analysis of changes in the finished goods level,

2) identification of the most important determinants of changes within the finished goods level,

3) assessment results of changes in the finished goods level.

The stages above are accompanied by an attempt to verify the hypotheses stated in the following form:

- H1 - An increase in the level of finished goods inventory in the examined mining enterprise mostly results from a lack of permanent cost advantages.

- $\mathrm{H} 2$ - Changes in the level of finished goods inventory in the examined mining enterprise are strongly connected with economic fluctuations in the global markets of energy resources, mostly the hard coal market.

In relation to the first research hypothesis, cost advantage is understood as the basic source of a price-competitive advantage. The companies that possess this advantage due to lower costs of manufacturing are able to offer lower prices for consumers and significantly expand their sales market (Skawińska 2002; Popek and Kłak 2009). In the case of hard coal producers, cost advantage should be considered as a key source of competitiveness because, taking into account the relative homogeneity of the final product and slight differentiation of the product range, the use of other sources of competitive advantage is of a much lower significance.

The second research hypotheses is related to a co-dependence of the markets for energy resources in the world that has been observed for years, and is still advancing. The results of research on this subject allow for the conclusion that the markets for non-renewable energy resources-crude oil, natural gas, and hard coal-are strongly connected with one another, which also results in the strong mutual price dependence of these resources. It is worth adding that in the last century, the price fluctuations of hard coal were much lower than the price fluctuations of natural gas and crude oil (Jang et al. 2012; Bo and Junhai 2011; Sun et al. 2013). In the 21 st century, mostly as a result of advancing globalisation, price fluctuations of hard coal have increased considerably. What is more, the strength of the connection of these prices with the prices of non-renewable substitutes for hard coal has increased as well.

In the last 14 years, the market for hard coal has been subject to significant internationalisation, which is confirmed by a strong correlation of price indexes of hard coal 
within particular geographical locations, which include Newcastle (Australia), Richards Bay (RSA), Bolivar (Colombia), Amsterdam, Rotterdam, Antwerp (ARA; Europe), and Japan. The research shows that it is not as strong a correlation as in the case of the prices of crude oil, which may be considered to be fully globally correlated, or natural gas because its prices are strongly regionally correlated. The main factors that influence the correlation level of the prices of hard coal in the global markets are thought to be the provisions of long-term coal trade contracts (Papież and Śmiech 2013; Li et al. 2009; Kamiński 2011).

In terms of the first research stage, statistical measures are adopted concerning the structure and dynamics of the examined phenomena. They are used to determine the share of inventory in total assets, to examine the internal structure of inventory, as well as to identify changes in total assets and their single components. The resource material consisted of the financial reports of the examined enterprise.

In the second research stage and using the aforementioned data, the role of hard coal in satisfying energy needs in Poland is described, the prices of the resources in the European market are compared with the cost of manufacturing in Poland, and the differences between hard coal production and consumption in Poland are calculated for the examined period. The factors above are treated as the key determinants of finished goods sales in the examined mining enterprise.

In the third research stage, the results are determined in terms of the excess inventory level using, among other things, the following ratios of financial analysis:

1. Inventory turnover in days:

$$
\frac{\text { material, merchandise, products sales revenues }}{\text { average level of inventory }} \times \frac{1}{365}
$$

2. Current ratio $^{2}$ :

$$
\frac{\text { current assets }}{\text { current liabilities }}
$$

3. Quick ratio:

$$
\frac{\text { current assets - inventory }- \text { short - term accruals }}{\text { current liabilities }}
$$

Furthermore, at this stage, changes in the level of operating cash flow are analysed, which are caused by a change in inventory. Furthermore, an attempt is made to estimate the costs of inventory financing using the level and average interest rates of current loans, shown in the

\footnotetext{
2 Current assets = operating assets - short-term trade receivables of payment deadline not exceeding 12 months. Current liabilities $=$ short-term liabilities - short-term trade payables of payment deadline not exceeding 12 months + short-term provisions + short-term accruals.
} 
statistics of the National Bank of Poland. Lastly, aside from the results of the aforementioned stages, the conclusion makes recommendations concerning possible solutions in terms of decreasing the level of finished goods inventory within the examined mining enterprise.

\subsection{Changes in the finished goods inventory}

in the mining enterprise in the years 2003-2012

In the examined enterprise, the material inventory is valued according to the purchase price with inclusion of revaluation in case of permanent value loss. The material consumption occurs according to the first-in first-out (FIFO) principle. On the balance sheet date, the material valuation is made using the purchase price but is not higher than the net sale price. Purchase, stock, and consumption of material is valued according to the purchase price decreased by the value of revaluation write-offs. In turn, the finished goods inventory is valued according to the real cost of manufacturing, which is accrued from the previous month, and in the case of balance sheet valuation, accrued from the last 12 months. The examined enterprise uses financial accounting in the process of determining the cost of manufacturing, not including management cost accounts.

In the examined enterprise, the share of finished goods inventory in the total assets has been fluctuating from around $1 \%$ to over $9 \%$ through the whole analysed period (Fig. 1).

For the years 2003-2008, the share of finished goods inventory in the balance sheet sum was relatively stable and placed in the range of 1-3\%. From 2009-2010, it increased significantly and then decreased in 2011, but in 2012 it peaked rapidly at an unusually high level, one not encountered previously in the history of the examined enterprise. The changes presented in Figure 1 were mostly caused by the change in the value of finished goods

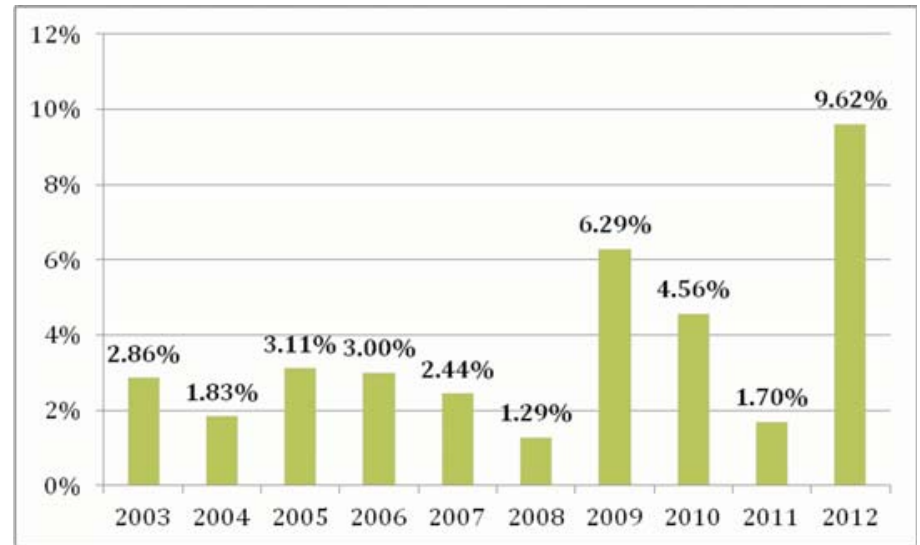

Fig. 1. Share of finished goods inventory in the total assets in the examined mining enterprise from 2003-2012 [\%]

Source: own work based on the financial reports of the examined mining enterprise

Rys. 1. Udział wyrobów gotowych w aktywach ogółem w badanym przedsiębiorstwie górniczym w latach 2003-2012 [\%] 
inventory because the balance sheet sum in the examined period was changing only to a small degree or was negatively correlated with the value of the finished goods inventory (Figs. 2 and 3).

As can clearly be seen from the data presented in Fig. 3, in 2012 the finished goods inventory exceeded the unsustainable unacceptable value of PLN 11 million. It is also worth adding that the unfavourable tendency was maintained in 2013 as well. In August 2013,

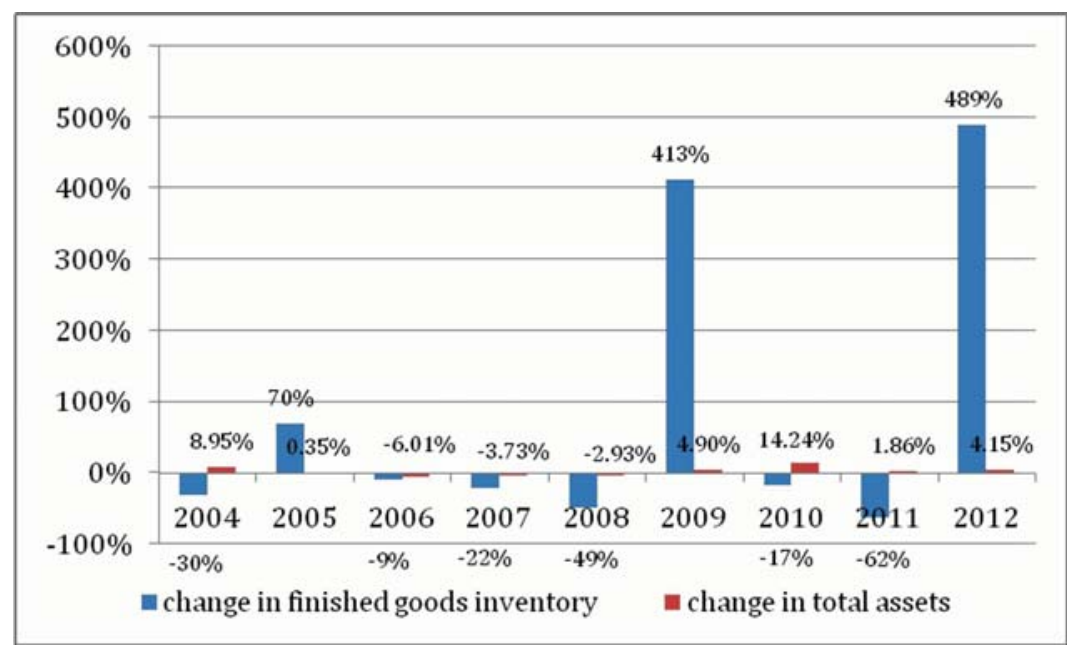

Fig. 2. Changes in the total assets and finished goods inventory in the examined mining enterprise from 2003-2012 [\%]

Source: own work based on the financial reports of the examined mining enterprise

Rys. 2. Zmiany w aktywach ogółem i wyrobach gotowych w badanym przedsiębiorstwie górniczym w latach 2003-2012 [\%]

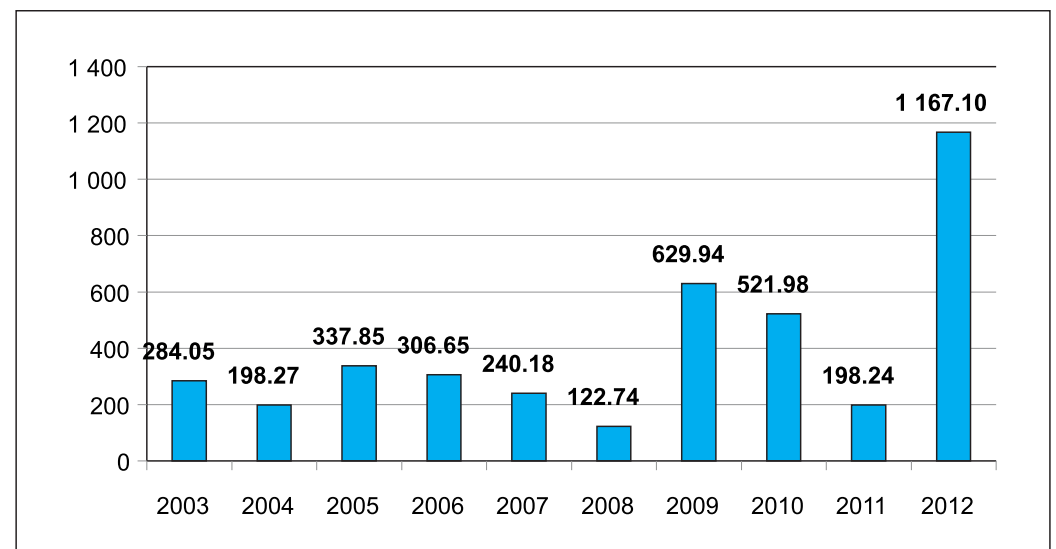

Fig. 3. Value of finished goods inventory in the examined mining enterprise from 2003-2012 [million PLN] Source: own work based on the financial reports of the examined mining enterprise

Rys. 3. Wartość wyrobów gotowych w badanym przedsiębiorstwie górniczym w latach 2003-2012 [mln zł] 
the value of finished goods inventory equalled over PLN 13 million, which means that the value increased further in relation to the end of 2012 when it equalled over $11 \%$.

Taking into account the variability of inventory, it is also worth looking at the internal structure of inventory in the examined mining enterprise (Table 1).

Table 1. Structure of inventory in the examined mining enterprise in the years 2003-2012 [\%]

Tabela 1. Struktura zapasów w badanym przedsiębiorstwie górniczym w latach 2003-2012 [\%]

\begin{tabular}{|l|r|r|r|r|r|}
\hline \multirow{2}{*}{ Specification } & \multicolumn{5}{c|}{ Years } \\
\cline { 2 - 6 } & 2003 & 2004 & 2005 & 2006 & 2007 \\
\hline Raw material & 22.195 & 30.517 & 15.330 & 18.815 & 22.948 \\
\hline Semi-finished products and work-in-progress & 0.000 & 0.000 & 0.101 & 0.122 & 0.101 \\
\hline Finished goods & 77.803 & 69.178 & 84.446 & 81.019 & 76.768 \\
\hline Merchandise & 0.000 & 0.094 & 0.000 & 0.000 & 0.000 \\
\hline Advance payments for products & 0.002 & 0.212 & 0.123 & 0.045 & 0.183 \\
\hline \multirow{2}{*}{ Specification } & & & Years & \\
\cline { 2 - 6 } & 2008 & 2009 & 2010 & 2011 & 2012 \\
\hline Raw material & 38.789 & 11.761 & 13.022 & 31.828 & 7.539 \\
\hline Semi-finished products and work-in-progress & 0.309 & 0.157 & 0.075 & 0.619 & 0.324 \\
\hline Finished goods & 60.824 & 88.070 & 86.854 & 67.474 & 92.101 \\
\hline Merchandise & 0.000 & 0.000 & 0.000 & 0.000 & 0.000 \\
\hline Advance payments for products & 0.079 & 0.012 & 0.049 & 0.079 & 0.037 \\
\hline
\end{tabular}

Source: own work based on the financial reports of the examined mining enterprise

The results from the data included in Table 1 show that the finished goods dominate in the total inventory throughout the examined period. Their share fluctuates from $60 \%$ to over $92 \%$. The second most dominant position in the structure of inventory is raw material with a share in the range of $11-38 \%$. The other components have a marginal share in the structure of total inventory. The range of finished goods in the examined enterprise is not varied. It is only differentiated by thickness and quality parameters, which include calorific value, sulphur content, and ash content.

It should also be noted that the variability of material value is low, whereas finished goods are specific for very rapid changes in time (Fig. 4). This is also confirmed by the variation coefficient, which equals $12.44 \%$ for raw materials and $73.44 \%$ for finished goods.

Based on the preliminary analysis of the levels and changes in the inventory of the examined enterprise, it is possible to arrive at the following conclusions:

1. Finished goods constitute a dominant part of the total assets.

2. Finished goods are relatively homogenous, and they are only differentiated by thickness and three basic quality parameters-calorific value, sulphur content, and ash content. 


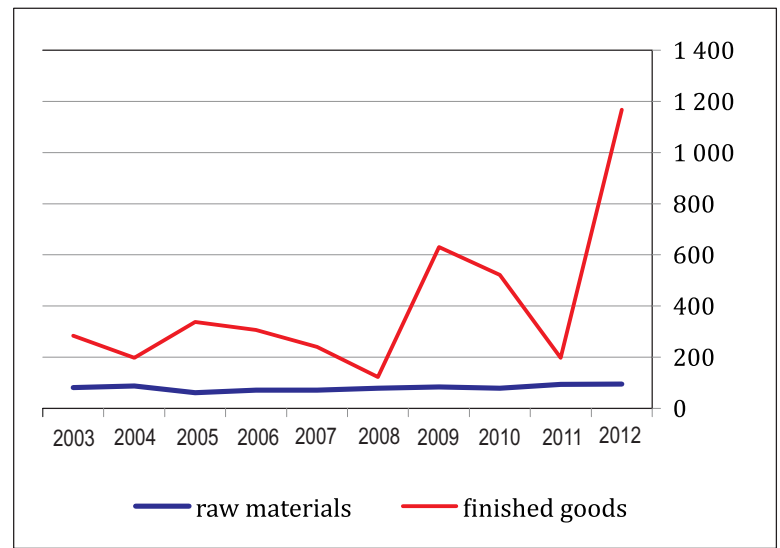

Fig. 4. Value of raw materials and finished goods in the examined mining enterprise in the years 2003-2012 [million PLN]

Source: own work based on the financial reports of the examined mining enterprise

Rys. 4. Wartość materiałów i wyrobów gotowych w badanym przedsiębiorstwie górniczym w latach 2003-2012 [mln zł]

3. Finished goods in the analysed period undergo significant fluctuations over time.

4. The value and share of finished goods in inventory and total assets increased substantially in the years 2012 and 2013, which confirms serious sales problems.

\subsection{Determinants of changes in finished goods inventory in the mining enterprise}

in the years 2003-2012

The key financial determinants of the levels of finished goods inventory in every enterprise are market demand, price, and cost of manufacturing of a finished good (de Vries 2013). The hard coal produced by the examined mining enterprise, which is owned by the State Treasury (Elsayed and Wahba 2013), as an energy resource has played a vital role for many years in satisfying the energy needs of the Polish economy (Olkuski 2011). This is confirmed by statistical data concerning the share of particular energy sources in satisfying those energy needs, presented in Table 2 .

The data included in Table 2 reveal that the share of coal has been systematically, but quite slowly, decreasing; however, coal still remains a strategic energy resource for Poland (Frączek and Kaliski 2012). The use of hard coal as an energy resource in Poland from 2006-2012, along with the value of its production, export, and import, is presented in Fig. 5.

According to the data presented in Fig. 5, coal use and production was decreasing until the year 2009. Since 2009, there has been growth in usage that is satisfied not only by domestic production but also by an increasing inflow of cheaper coal from imports (Olkuski 2013), mainly from Russia, Kazakhstan, and the US (Stala-Szlugaj and Klim 2012). On the basis of such data, one may conclude that the examined mining enterprise possessed 
Table 2. Share of particular energy sources in satisfying energy needs in Poland from 2003-2012

Tabela 2. Udział poszczególnych źródeł energii w zaspokajaniu potrzeb energetycznych w Polsce w latach 2003-2012

\begin{tabular}{|l|r|r|r|r|r|r|r|r|r|c|}
\hline \multirow{2}{*}{ Specification } & \multicolumn{10}{|c|}{ Years } \\
\cline { 2 - 12 } & 2003 & 2004 & 2005 & 2006 & 2007 & 2008 & 2009 & 2010 & 2011 & 2012 \\
\hline Hard coal & 64.10 & 62.65 & 61.07 & 61.27 & 60.53 & 58.17 & 56.36 & 56.66 & 56.18 & 55.29 \\
\hline Crude oil & 22.43 & 23.59 & 24.56 & 24.64 & 25.26 & 26.29 & 27.42 & 26.84 & 26.67 & 25.75 \\
\hline Natural gas & 12.50 & 13.00 & 13.42 & 13.06 & 12.93 & 13.98 & 14.09 & 14.03 & 14.18 & 15.28 \\
\hline Hydropower & 0.83 & 0.52 & 0.55 & 0.49 & 0.56 & 0.51 & 0.58 & 0.66 & 0.53 & 0.47 \\
\hline $\begin{array}{l}\text { Other renewable } \\
\text { resources }\end{array}$ & 0.15 & 0.25 & 0.41 & 0.54 & 0.73 & 1.05 & 1.55 & 1.81 & 2.45 & 3.21 \\
\hline
\end{tabular}

Source: own work based on BP Statistical Review of World Energy, June 2013

the output market, and it will continue in the domestic industrial energy market on the condition that it will deliver hard coal of a proper quality and at a competitive price . $^{3}$

It is worth emphasising that the global hard coal market is characterized by its high price fluctuations that depend on, among other things, the demand and price of substitute renewable energy sources as well as the pace of development of renewable energy sources, which is also affected by progressing decarbonisation (Bednorz 2012; Dubiński and Turek 2012). In such changing price conditions, a necessary requirement of hard coal compe-

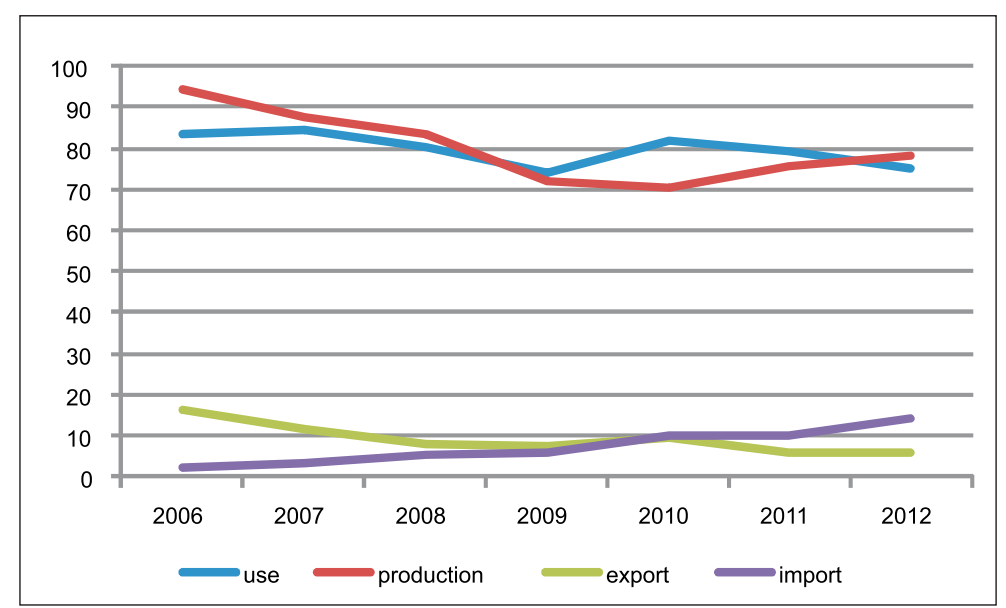

Fig. 5. Hard coal use, production, export, and import in Poland from 2006-2012 [million tons] Source: own work based on the data of the Central Statistical Office and Ministry of Economy

Rys. 5. Zużycie, produkcja, eksport i import węgla kamiennego w Polsce w latach 2006-2012 [mln ton]

${ }^{3}$ Quality parameters of Polish hard coal are subject to the proper technological processes in the mechanical processing plant and currently do not rise concerns of the recipients. 
titiveness for the examined mining enterprise is to provide stable and low level unit costs (Jonek-Kowalska 2011b). The value of these costs is listed in Fig. 6, where they are compared to the unit hard coal price in the European market from 2003-2012.

Fig. 6 reveals that the unit cost of manufacturing for the examined enterprise has been systematically rising over time. The increase was especially intensive from 2008-2012. However, the price changed in a cyclical manner, reaching the highest values in the years 2004, 2008 and 2011. At those times, the levels of finished goods were the lowest for the examined enterprise (Fig. 4). When in 2005, 2009 and 2012 the price rapidly declined, the level of finished goods clearly increased (Fig. 4). In these periods, with rising unit costs, the hard coal mined by the examined enterprise stopped being competitive in terms of price, followed by problems with sales. The enterprise does not have a cost advantage, which is a requirement for a price advantage.

It is also worth noting the year 2012 in detail, as this is when inventory reached a record level in the history of the examined enterprise, connected not only with an unfavourable relation of unit cost of manufacturing to price, but also with the rapid excess production of hard coal in Poland (Fig. 5).

According to the data presented in Fig. 5, until the year 2009, hard coal production in Poland had been systematically decreasing. In 2010, as a consequence of the fall in prices in 2009, demand and consumption increased rapidly, which in turn caused a lack of hard coal that triggered price increases in 2011. Price breakdown in 2012, with further

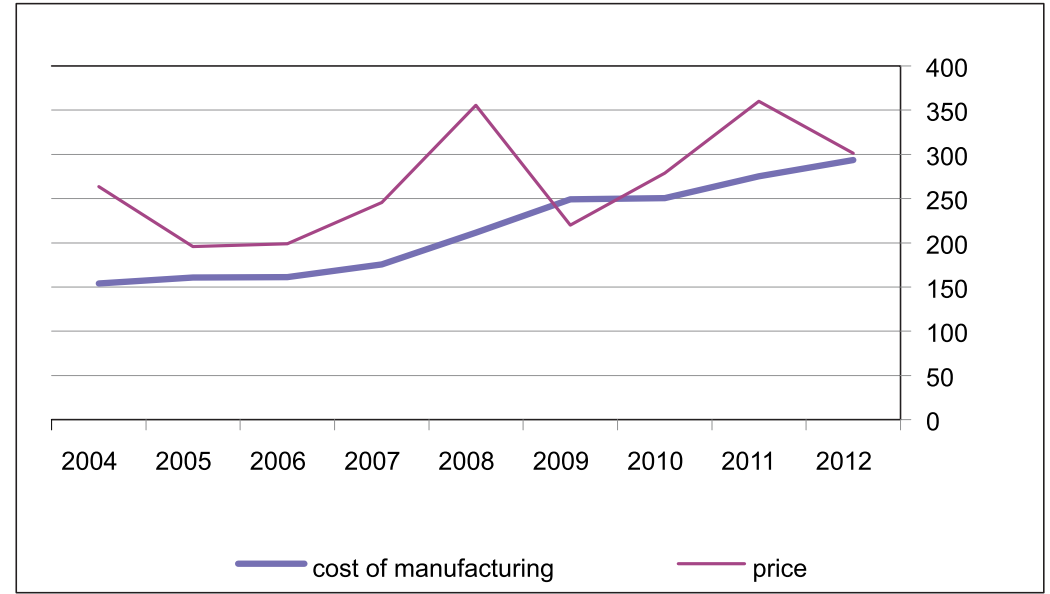

Fig. 6. The price of hard coal in the European market and unit cost of manufacturing for the examined mining enterprise from 2003-2012 [PLN/Mg]

Source: own work based on the financial reports of the examined mining enterprise (for unit cost of manufacturing) and McCloskey Coal Information Service

(for unit price-yearly values calculated on the basis of average weekly prices using the average yearly dollar exchange rate published by the National Bank of Poland)

Rys. 6. Cena węgla kamiennego na rynku europejskim i jednostkowy koszt produkcji w badanym przedsiębiorstwie górniczym w latach 2003-2012 [zł/Mg] 
unit cost growth and considerable excess production, generated a sudden and intensive inventory rise for the examined enterprise in 2012. The situation also deteriorated with the increasing level of imports, which were not only price competitive but also characterized by a quality advantage. In 2013, the average calorific value of imported power coal equalled $23,777 \mathrm{~kJ} / \mathrm{kg}$, while the calorific value of domestic coal equalled only $22,165 \mathrm{~kJ} / \mathrm{kg}$. The sulphur level of the imported coal amounted to $0.52 \%$, but reached $0.83 \%$ for the domestic coal. The ash content of the imported coal was $11.9 \%$, while for the Polish coal ash content was $18.3 \%{ }^{4}$.

On the basis of the data presented above, it can be concluded that the hard coal in Poland is a strategic energy resource, but the examined mining enterprise has problems with its sales due to the periodically unfavourable relation of market price to unit cost of manufacturing rising over time. This confirms the $\mathrm{H} 1$ hypothesis, according to which the rise in finished goods inventory levels in the examined mining enterprise has mostly resulted from a lack of permanent cost advantage.

During the periods of falling market prices, the finished goods inventory was rapidly increasing, reaching a record level in 2012. On the other hand, the price rise constituted an impulse for selling excessive stock. This confirms the $\mathrm{H} 2$ hypothesis, according to which the changes in the level of finished goods inventory in the examined enterprise are strongly connected with economic fluctuations in the global markets for energy resources, mainly the hard coal market. Nevertheless, this hypothesis requires supplementation, as in the year 2012 the high level of finished goods inventory was also affected by the excess production of hard coal triggered by a favourable market situation in 2011, as well as by an increase in hard coal imports specifically enjoying superior price and quality competitiveness. The examined enterprise did not react in advance to the observed, cyclical character of the market for hard coal, which manifests itself in considerable demand and price fluctuations and also changes the sources of demand satisfaction.

\subsection{Financial effects of changes in the finished goods inventory of the mining enterprise in the years 2003-2012}

One of the direct effects of growth in inventory levels is prolonging the turnover cycle, which is presented in Fig. 7. The period of inventory turnover, besides the year 2003 when the examined enterprise was established, was the longest in 2009; the highest level of inventory appeared in 2012 (Jonek-Kowalska 2011a).

Prolongation of the inventory turnover cycle and an increase in the level of inventory has had an indirect impact on the level of financial liquidity. According to the data presented in Fig. 8, the examined mining enterprise shows no current and quick liquidity throughout the period analysed. Moreover, quick liquidity considerably decreases in the periods of inventory growth and then, using the most liquid operating assets,

\footnotetext{
4 Data of Industrial Development Agency.
} 


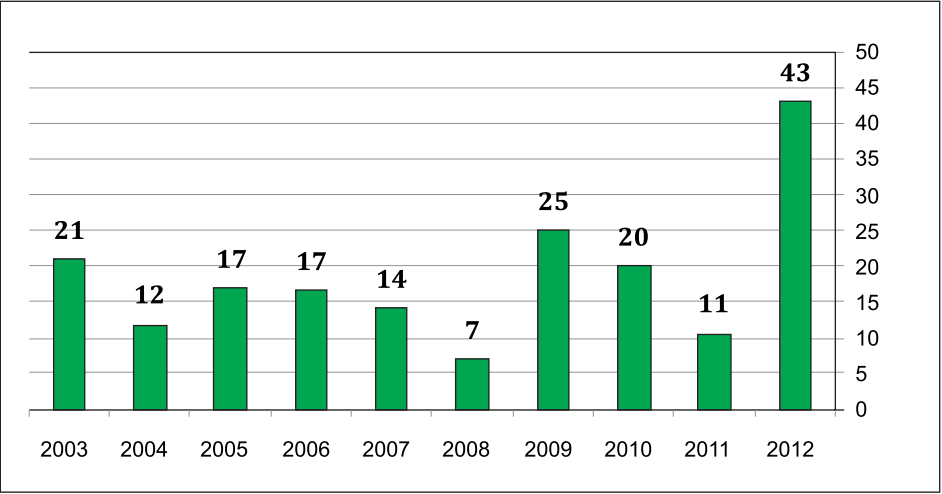

Fig. 7. Inventory turnover ratio for the examined enterprise in the years 2003-2012 [days] Source: own work based on the financial reports of the examined mining enterprise

Rys. 7. Wskaźnik rotacji zapasów w badanym przedsiębiorstwie w latach 2003-2012 [dni]

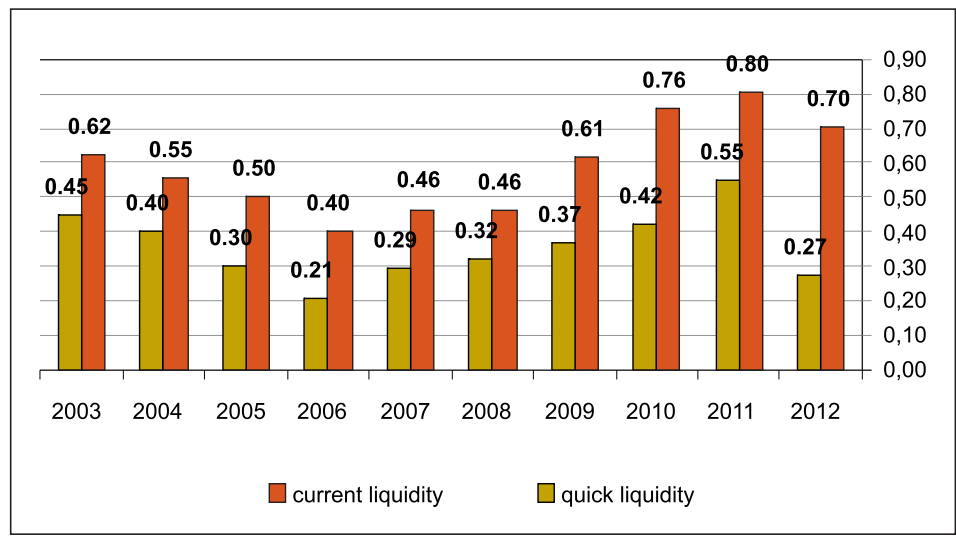

Fig. 8. Quick and current ratio in the examined mining enterprise in the years 2003-2012 Source: own work based on the financial reports of the examined mining enterprise

Rys. 8. Wskaźniki płynności bieżącej i szybkiej w badanym przedsiębiorstwie w latach 2003-2012

the enterprise may settle only $27 \%$ to $37 \%$ of current liabilities (Turek and Jonek-Kowalska 2009).

Freezing financial sources in inventory, as mentioned in the introduction, also affects the level of operating cash flow, the value of which in the examined period is presented in Fig. 9.

As mentioned in the beginning of the article, the indirect inventoriable cost is the cost of freezing financial resources in inventory. The estimated value of this cost in the given years is presented in Table 3. It was calculated as a multiplication of average credit interest in the current account and the value of inventory in a given accounting year. The interest value was 


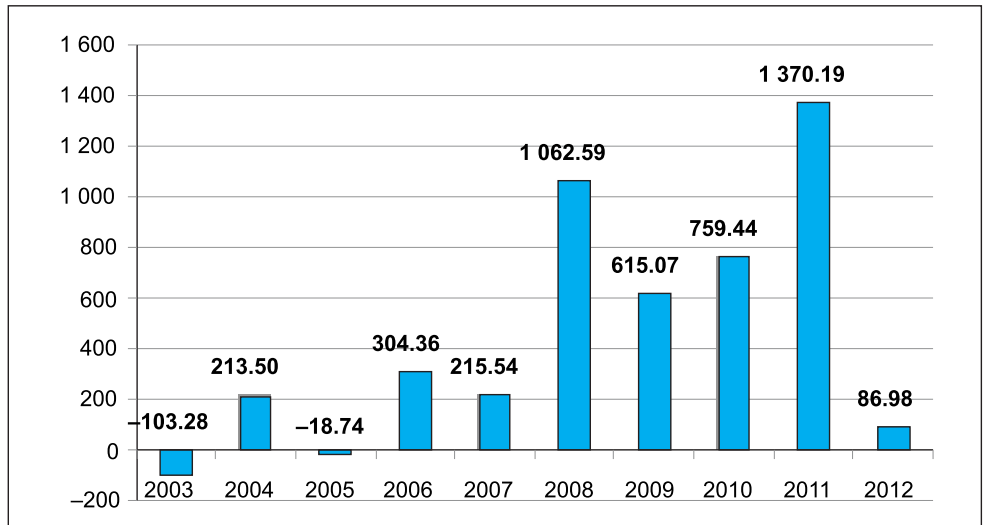

Fig. 9. Value of operating cash flow of the examined enterprise in the years 2003-2012 [million] Source: own work based on the financial reports of the examined mining enterprise Rys. 9. Wartość operacyjnych przepływów pieniężnych w badanym przedsiębiorstwie w latach 2003-2012 [mln]

Table 3. Value of inventory, average credit interest in current account, and potential cost of inventory financing in the examined mining enterprise in the years 2005-2012

Tabela 3. Wartość zapasów, średnie oprocentowanie kredytów w rachunku bieżącym i potencjalne koszty finansowania zapasów w badanym przedsiębiorstwie górniczym w latach 2005-2012

\begin{tabular}{|l|c|c|c|c|}
\hline \multirow{2}{*}{\multicolumn{1}{c|}{ Specification }} & \multicolumn{4}{c|}{ Years } \\
\cline { 2 - 5 } & 2005 & 2006 & 2007 & 2008 \\
\hline Interest [\%] & 6.98 & 5.87 & 7.13 & 7.13 \\
\hline Value of inventory [PLN] & $400,072,220$ & $378,497,815$ & $312,859,309$ & $201,798,141$ \\
\hline Financing cost [PLN] & $27,935,043$ & $22,198,897$ & $22,299,047$ & $14,383,162$ \\
\hline \multirow{2}{*}{ Specification } & \multicolumn{4}{|c|}{ Years } \\
\cline { 2 - 6 } & 2009 & 2010 & 2011 & 2012 \\
\hline Interest [\%] & 6.01 & 6.07 & 6.41 & 6.75 \\
\hline Value of inventory [PLN] & $715,276,804$ & $600,982,837$ & $293,800,499$ & $1,267,191,058$ \\
\hline Financing cost [PLN] & $43,011,978$ & $36,449,609$ & $18,820,370$ & $85,545,956$ \\
\hline
\end{tabular}

Source: own work based on the financial reports of the examined mining enterprise and NBP data (yearly interest calculated on the basis of monthly averages)

determined on the basis of data published by the National Bank of Poland (Sierpińska and Bąk 2012; Michalak 2011, 2012).

The estimated cost of inventory financing is the highest in the periods when inventory reached the highest level-that is, in the years 2005, 2009 and 2012. Moreover, this cost greatly increases over time. In 2005, it equalled almost PLN 30 million; in 2009, over 
PLN 43 million, and in 2012 it was at a record level amounting to over PLN 85.5 million. In the periods when the level of inventory did not increase, the level of cost of inventory financing was in the range of PLN 14-22 million.

\section{Summary and conclusions}

Given the considerations and research undertaken in this study, it can be concluded that for the examined mining enterprise, there are periods of excess levels of finished goods inventory. Excess inventory, indicating problems with sales, occurred in the years 2005, 2009 and 2012. However, the level of inventory systematically grew throughout the period examined.

The finished goods offered by the enterprise are relatively homogenous, and their quality parameters do not experience great fluctuations over time. The preferences of consumers, which are mainly within the industrial energy sector, do not change either. Among the vital changes that influence hard coal demand, there may be-above all-changes in the structure of sources satisfying energy needs in Poland, and price fluctuations within the global hard coal market. Yet the first of these two factors advances slowly in light of the data presented, so it is not the main reason for sales deterioration and stock accumulation. The value of finished goods inventory in the examined mining enterprise reaches its highest values in the periods when the prices of hard coal in the European market are the lowest. At that time, the mining enterprise loses the advantage of price competitiveness, as it does not control the unit cost of manufacturing which systematically increases throughout the entire analysed period. The arguments above and the data presented confirm the hypotheses stated in the article that the increase in the level of finished goods inventory in the examined mining enterprise mostly results from a lack of permanent cost advantage (H1), and that changes in the level of finished goods inventory in the examined enterprise are strongly connected with economic fluctuations in the global market for energy resources-mostly the hard coal market (H2).

The effects of excess levels of inventory include prolonging the turnover cycle in days, decreasing the level of quick liquidity, and clearly decreasing the operating cash flow. In addition, the enterprise has to settle the indirect inventoriable costs, losing the possibility of using the resources frozen in inventory in an alternative way, as well as searching for additional sources of financing operating activities. Consequently, the average cost of inventory financing equalled PLN 14 to 22 million in periods of average levels of inventory, and in the periods of strong increase grew to PLN 30.43 to 85.5 million.

With these facts in mind, the most important task of the examined enterprise should be a reduction, or at least a freezing of the increase in the unit cost of manufacturing. The sales market may then be guaranteed for the existing and future hard coal supplies. In order to achieve such an objective, the cost of manufacturing and the cost of product sales should be determined precisely for the purposes of not only financial accounting, but primarily management accounting, and oriented at the identification of potential sources of non- 
-effectiveness. Furthermore, payment increases should be halted, and the remuneration system should be linked with work effectiveness as the remuneration costs regarding payroll charges currently constitute over $50 \%$ of total costs; their rise is thus the main trigger for the increase in the unit cost of manufacturing. It is difficult to consider the reduction of finished goods inventory and sales improvement without taking drastic and immediate action.

\section{REFERENCES}

AA 1994. Act of $26^{\text {th }}$ September 1994 on Accounting (Dz.U.2013.330) (in Polish).

Agrawal, N. and Smith, S.A. 2013. Optimal inventory management for a retail chain with diverse store demands. European Journal of Operational Research 225(3), pp. 393-403.

Andersson et al. 2010 - Andersson, H., Hoff, A., Christiansen, M., Hasle, G. and Lřkketangen, A. 2010. Industrial aspects and literature survey: Combined inventory management and routing. Computers \& Operations Research 37(12), pp. 2041-2061.

Bąk, M. ed. 2003. Financial accounting. Wroclaw: Wroclaw University of Economics, 192 p. (in Polish).

Bednorz, J. 2012. The decarbonisation of the European Union as a threat to its energy security and sustainable development. Polityka Energetyczna - Energy Policy Journal 15(3), pp. 181-195 (in Polish).

Bo, Z. and Junhai, M. 2011. Price Index Forecast by a New Partial Least Squares Regression. Procedia Engineering 15 , pp. 5025-5029.

Czerny, J. 2009. Financial accounting. Selected issues. Poznan: Higher School of Trade and Accounting, 319 p. (in Polish).

Dadacz, J. 2012. National Accounting Standards with the Accounting Act. Gdansk: Centre for Consultancy and Training Personnel Ltd, 780 p. (in Polish).

de Vries, J. 2013. The influence of power and interest on designing inventory management systems. International Journal of Production Economics 143(2), pp. 223-241.

Dubiński, J. and Turek, M. 2012. Opportunities and threats for the development of coal mining in Poland. Wiadomości Górnicze - Mining News 11, pp. 626-633 (in Polish).

Elsayed, K. and Wahba, H. 2013. Reinvestigating the relationship between ownership structure and inventory management: A corporate governance perspective. International Journal of Production Economics, 143(1), pp. 207-218.

Frączek, P. and Kaliski, M. 2012. The Deregulation of Natural Gas Markets and its Consequences for Gas Recipients in the EU. Archiwun Górnictwa - Archives of Mining Sciences 54(4), pp. 739-752.

Gabrusewicz, W. ed. 2005. Functions of accounting in corporate management. Scientific Papers of Poznan University 60. Poznan: Poznan University of Economics, 168 p. (in Polish).

Godziszewski B. 2001. Resource conditions of corporate strategy. Torun: UMK, 208 p. (in Polish).

Grądzka, C. 2009. Models of cost accounts [In:] Szczęsny, W. and Turyna, J. eds. Financial conditions for the development of business organizations. Theory and practice of budgeting. Warsaw: University of Warsaw, 507 p. (in Polish).

Guan, Z. and Zhao, X. 2011. Pricing and inventory management in a system with multiple competing retailers under (r, Q) policies. Computers \& Operations Research 38 (9), pp. 1294-1304.

Hamisu et al. 2013 - Hamisu, A.A., Kabantiok, S. and Wang, M. 2013. Refinery scheduling of crude oil unloading with tank inventory management. Computers and Chemical Engineering 55, pp. 134-147.

Jang et al. 2012 - Jang, Ch.J., Xuan, X. and Jacson, R.B. 2012. China's coal price disturbances: Observations, explanations implications for global energy economies. Energy Policy 51, pp. 720-727.

Jonek-Kowalska, I. 2011a. Examination of financial conditions in operational activity of mining enterprises [In:] Turek, M. ed. Models of financing operational activity of mining enterprises. Katowice: GIG, pp. 117-136 (in Polish). 
Jonek-Kowalska, I. 2011b. Evaluation of the costs of manufacturing, oriented to improve the efficiency of the Polish hard coal mining. Zeszyty Naukowe Uniwersytetu Szczecińskiego - Scientific Papers of University of Szczecin 639, Finance, Financial Market and Insurances 37, pp. 49-58 (in Polish).

Kamiński J. 2011. Market power in a coal-based power generation sector: The case of Poland. Energy 36, pp. 6634-6644.

Kiedrowska, M. ed. 2004. Financial accounting. Poznan: Poznan University of Economics, 182 p.

Li et al. 2009 - Li, A.B., Zhou, B. and Lu, M.Y. 2009. Economic analysis and realization mechanism design for full cost of coal mining. Procedia Earth and Planetary Science 1, pp. 1686-1694.

Magda et al. 2009 - Magda, R., Głodzik, S., Jasiewicz, J. and Woźny, T. 2009. Concept of an Information System Supporting the use of Technical Means of Production in the Design of Mine Workings. Archiwum Górnictwa - Archives of Mining Sciences 54(1), pp. 79-86.

Mason et al. 2012 - Mason, A., Shaw, A. and Al-Shamm, A. 2012. Peer-to-peer inventory management of returnable transport items: A design science approach. Computers in Industry 63(3), pp. 265-274.

Michalak, A. 2011. The problems of operational activity financing of mining enterprises in Poland [In:] Theory of Management 3. Zilina: University of Żilina, pp. 34-39.

Michalak, A. 2012. Dilemmas of Equity Cost Calculation in Polish Mining Enterprises. Journal of US-China Public Administration 9(9), pp. 1008-1019.

Nowak, E. 2010. The cost account in an enterprise. Wroclaw: Expert Publishing and Consulting, 263 p. (in Polish).

Olkuski, T. 2011. Coal - the most reliable source of energy. Przeglad Górniczy-Mining Review 7-8, pp. 42-45 (in Polish).

Olkuski, T. 2013. Hard coal import dependence of Poland. Gospodarka Surowcami Mineralnymi - Mineral Resources Management 29(3), pp. 115-130 (in Polish).

Ozguven, E.E. and Ozbay, K. 2013. A secure and efficient inventory management system for disasters. Transportation Research Part C 29, pp. 171-196.

Papież, M. and Śmiech, S. 2013. Causality-in-mean and causality-in-variance within the international steam market. Energy Economics 36, pp. 594-604.

Popek, S. and Kłak, D. 2009. Creation of competitive advantage based on product quality. Przedsiębiorstwo i Region - Enterprise and Region 1 pp. 27-37 (in Polish).

Probierz, K. and Marcisz, M. 2010. Estimation of the Hard Coal Quality in a Deposit in View of National and International Standards. Archiwum Górnictwa - Archives of Mining Sciences 55(4), pp. 847-863.

Relvas et al. 2013 - Relvas, S., Magatao, S.N.B., Barbosa-Povoa, A.P.F.D. and Neves, Jr. F. 2013. Integrated scheduling and inventory management of an oil products distribution system. Omega 41(6), pp. 955-968.

Samelak, J. 2005. The concept of a financial statement according to the Conceptual Framework and the International Standard No. 1 and Polish accounting law [In:] Gabrusiewicz, W. ed. The functions of accounting in corporate management. Szczecin: University of Szczecin, pp. 45-69 (in Polish).

Schwartz et al. 2006 - Schwartz, J.D., Wang, W. and Rivera, D.E. 2006. Simulation-based optimization of process control policies for inventory management in supply chains. Automatica 42(8), pp. 1311-1320.

Sierpińska, M. and Bąk, P. 2012. Financial structure of mining sector companies during an economic slowdown. Archiwum Górnictwa - Archives of Mining Sciences 57(4), pp. 1089-1100.

Sierpińska, M. and Jachna, T. 2007. Methods of financial decision-making: an analysis of examples and cases. Warsaw: PWN, 604 p. (in Polish).

Skawińska, E. 2002. Competitiveness of enterprises-a new approach. Warsaw-Poznan: PWN, 232 p. (in Polish).

Sobańska, I. ed. 2009. The cost account. Warsaw: C. H. Beck, 509 p. (in Polish).

Stala-Szlugaj, K. and Klim, A. 2012. Russian and Kazakh coal in the Polish market. Polityka Energetyczna Energy Policy Journal 15(4), pp. 229-240 (in Polish).

Sun et al. 2013 - Sun, Q., Xu, W. and Xiao, W. 2013. An empirical estimation for mean-reverting coal prices with long memory. Economic Modelling 33, pp. 174-181.

Szczęsny, W. and Turyna, J. eds. 2009. Financial conditions for the development of business organizations. Theory and practice of budgeting. Warsaw: University of Warsaw, 507 p. (in Polish).

Turek. M. 2013. Costs as a primary factor in determining operational activity of coal mines [In:] Turek, M. ed. Analysis and evaluation costs in the coal mining industry in Poland. Warsaw: Difin, pp. 111-122 (in Polish). 
Turek, M. and Jonek-Kowalska, I. 2010. The concentration of industrial enterprises. The causes, stages and effects. Gliwice: Silesian University of Technology, 147 p. (in Polish).

Turek, M. and Jonek-Kowalska, I. 2009. Assessment of financial liquidity as a criterion in decision-making in mining enterprises [In:] Szkoła Eksploatacji Podziemnej 2009 - School of Underground Mining 2009. Cracow: The Mineral and Energy Economy Research Institute of Polish Academy of Science, pp. 115-125 (in Polish).

Turek, M. and Michalak, A. 2013. The total and unit costs of production in coal mines - changes and determinants [In:] Turek M ed. Analysis and evaluation costs in the coal mining industry in Poland. Warsaw: Difin, pp. 57-64 (in Polish).

Turyna, J. 2008. Financial accounting. Warsaw: C. H. Beck, 307 p. (in Polish).

Walińska, E. ed. 2010. Financial accounting. Warsaw: Wolters Kluwer Publishers, 477 p. (in Polish).

Wanke, P.F. 2008. The uniform distribution as a first practical approach to new product inventory management. International Journal of Production Economics 114(2), pp. 811-819.

Xu et al. 2012 - Xu, Y., Wanga, L., Chen, Z., Shan and S., Xia, G. 2012. Optimization and adjustment policy of two-echelon reservoir inventory management with forecast updates. Computers \& Industrial Engineering 63(4), pp. 890-900.

Yüzgec et al. 2010 - Yüzgec, U., Palazoglu, A. and Romagnoli, J.A. 2010. Refinery scheduling of crude oil unloading, storage and processing using a model predictive control strategy. Computers and Chemical Engineering 34(10), pp. 1671-1686.

Zarzecki, D. ed. 2011. Scientific Papers University of Szczecin 639, Finance, Financial Market, Insurances, 37. Szczecin: University of Szczecin (in Polish)

\section{FINANSOWE ASPEKTY ZMIAN POZIOMU ZAPASÓW PRODUKTOW GOTOWYCH W PRZEDSIĘBIORSTWIE GÓRNICZYM}

\section{Słowa kluczowe}

nadmierne zapasy, determinanty zapasów w przedsiębiorstwach górniczych, skutki utrzymania nadmiernych zapasów, finanse w polskim górnictwie węgla kamiennego

\section{Streszczenie}

W niniejszym artykule problem badawczy sformułowano następująco: Jakie czynniki wpływają na zmiany poziomu zapasów w polskich przedsiębiorstwach górniczych i jakie są finansowe konsekwencje tych zmian? Zgodnie z wynikami przeprowadzonych analiz wśród istotnych zmian wpływających na zapotrzebowanie na węgiel kamienny można wskazać przede wszystkim zmiany w strukturze źródeł zaspokajania potrzeb energetycznych w Polsce oraz zmienność cen na międzynarodowych rynkach węgla kamiennego. Przy czym pierwsze $\mathrm{z}$ wymienionych, w świetle przedstawionych danych, postępują stosunkowo wolno, nie są więc główną przyczyną pogorszenia zbytu i kumulacji zapasów.

Do skutków nadmiernego poziomu zapasów należy zaliczyć: wydłużenie cyklu obrotowości zapasów w dniach, obniżenie poziomu płynności szybkiej oraz wyraźne zmniejszenie operacyjnych przepływów pieniężnych. Przedsiębiorstwo ponosi także pośrednie koszty utrzymania zapasów, tracąc możliwości alternatywnego wykorzystania środków zamrożonych w zapasach oraz poszukując dodatkowych źródeł finansowania działalności operacyjnej. 


\title{
FINANCIAL ASPECTS OF CHANGES IN THE LEVEL OF FINISHED GOODS INVENTORY
} IN A MINING ENTERPRISE

\author{
Key words \\ excessive stock, determinants of inventory in mining enterprise, \\ effects of maintaining excess inventory
}

\begin{abstract}
The research problem in this article is formulated as follows: which factors influence the changes in inventory levels in Polish mining enterprises, and what are the financial consequences of such changes? Based on the results of analyses conducted on vital changes affecting demand for hard coal, it may be necessary to implement certain changes (above others) in the structure of the sources of satisfying the energy needs of Poland, given price fluctuations in the global hard coal markets. However, the changes in the structure advance relatively slowly in light of the data presented; therefore, they are not the main reason for sales deterioration and stock accumulation. The main reason is increasing unit costs leading to a lack of price competitiveness when global coal prices fall below a certain level.

The effects of an excess inventory level includes prolonging the inventory turnover cycle in days, decreasing the level of quick liquidity, and clearly decreasing operating cash flow. The enterprise also has to bear indirect inventoriable costs, losing the possibility of alternative use of the financial resources that are frozen in inventory, while searching for additional financing sources for the operating activities.
\end{abstract}

